\title{
Space Vector Pulse Width Modulation Based Induction Motor with V/F Control
}

\author{
Vikramarajan Jambulingam \\ Electrical and Electronics Engineering, VIT University, India
}

\begin{abstract}
In adjustable speed drive system speed control techniques are generally essential. Therefore in order achieve this it requires variable voltage supply and frequency which is invariably obtained from a three-phase Voltage source inverter. Even though there are numbers of pulse width modulations scheme is used to obtain variable frequency and voltage supply from an inverter. It is less used than the space vector pulse width modulation. Because the SVPWM has several merits such as better dc bus utilization, easier digital realization over the other Pulse width modulation methods. In the space vector pulse modulation method with voltage / frequency control of induction motor drive is widely used in medium performance drive system. It is due to its characteristics like good power factor, extremely rugged and high efficiency. This scheme leads to be able to adjust the speed of the motor by control the frequency and amplitude of the stator voltage, the ratio of stator voltage to frequency should be kept constant. In this paper the voltage source inverter type space vector pulse width modulation model design and implementation has been done through MATLAB / SIMULINK software for the speed control of induction motor. In addition to these parameters like stator current, rotor current, torque and speed are obtained graphically.
\end{abstract}

Keywords: SVPWM, V/F Control, Induction motor, Pulse Width Modulation

\section{Introduction}

The induction motor or asynchronous is the most widely used electrical drive. [1] Has explained the complete analysis of electrical machinery drive system. Actually because independent control of torque and flux separately excited dc drives are simpler in control. Due to ruggedness, efficiency and simplicity the induction motors have been used in several applications for over a century. [2-3] has presented the analysis and simulation model development of induction motor in MATLAB / SIMULINK software. In addition to that the induction motors involve a corresponding control of stator current magnitude and the phase, making it a complex control. The stator flux linkages can resolve along any frame of reference. For this action it requires position of flux linkage at every instant. In addition to this the control of the ac machine is very similar to that of separately excited direct current motor and also this type of control involves field coordination. So it is also called as field oriented control [vector control].

The vector control is divided in to two types on the basis of method of measurement. They are indirect and direct vector control. Therefore in the case of direct vector control, the flux measurement is done by using the flux sensing coils or the Hall devices. But in case of indirect vector control the flux angle is not calculated directly, but it is predicted from the equivalent circuit model and from measurements of the stator current, voltage and rotor speed. The Main reasons for two level inverter topologies is to provide a three phase voltage source, where the phase, frequency of the voltage and amplitude, phase should always be controllable. SVPWM technique is widely used in rectifier and inverter controls. In SV pulse width modulation inverter the voltage utilization factor can be increased to 0.906 , normalized to that of the six step operation. The SP Pulse Width Modulation can be obtained by suitably adding a zero-sequence voltage to the original modulation waveform. The motor-control issues are conventionally handled by fixed gain PI and PID controllers.

\section{Space Vector Pulse Width Modulation Principle}

The space vector pulse width modulation technique is frequently used in direct torque control drive and vector control drive. In addition to this when current control is exercised in rotating reference frame. The reference voltage generation is used in particularly for vector control drives.

The vector forms the hexagon as shown in figure.1. At the same time it consists of six sector spanning 60 degree each. Actually it consist of eight switching states which includes two zero states and six active states generated by the voltage source inverter. The three phase voltage is represented by reference vector and it is generated by using space vector pulse width modulation by switching between two nearest active vectors and zero vectors.

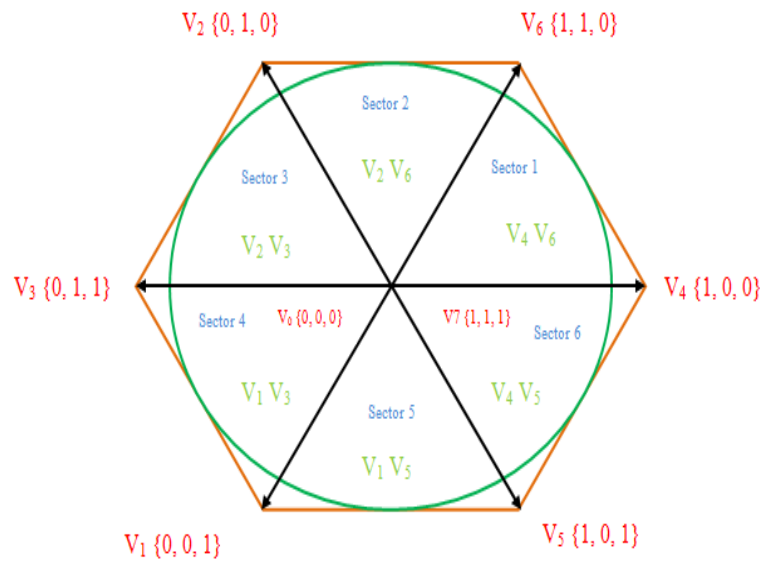

Figure 1: Space vector diagram for three level inverter

\section{Volume 5 Issue 2, February 2016}




\section{International Journal of Science and Research (IJSR) \\ ISSN (Online): 2319-7064}

Index Copernicus Value (2013): 6.14 | Impact Factor (2014): 5.611

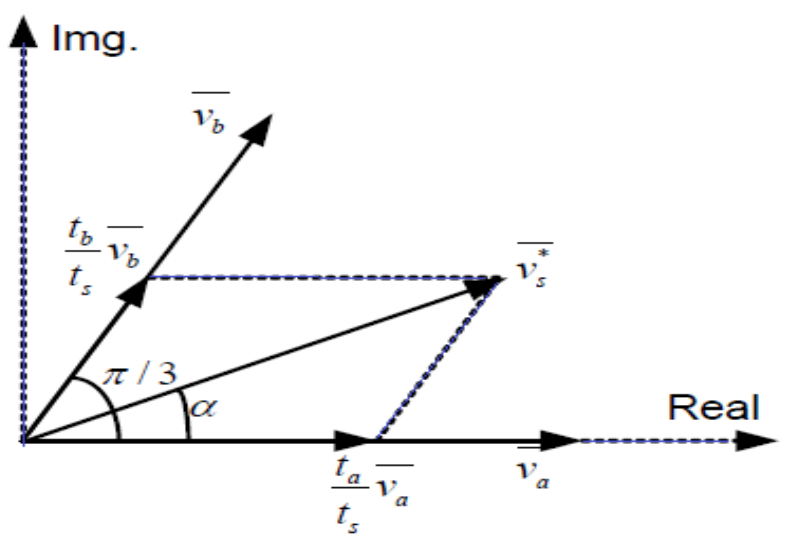

Figure 2: Space vector time calculation

The above figure. 2 has to be taken in to account to calculate time of application of different vectors. At the first sector depict the position of different available space vectors and reference vectors. In each leg the changes takes place only once in one switching period to obtain optimum harmonic performance and fixed switching frequency from space vector pulse width modulation. This can be achieved by applying zero state vectors followed by two adjacent active vectors in half switching period and in the next half of the switching period it contains the mirror image of the first half. In this case the total switching period is divided in to seven parts after that the, $0^{\text {ce }}$ vector is applied for one fourth of the total ,, $0^{\text {ec }}$ vector time first and then followed by the application of active vectors for half of their application time and then again , , ${ }^{\circ e}$ vector is applied for one fourth of, $0^{\text {ee }}$ vector time. Now once again this is repeated in the next half of the switching period. This is repeated in the next half of the switching period. This is how the space vector pulse width modulation is obtained. The leg voltage and space vector disposition for one switching period in sector 1 is shown in figure.3. [4-8] has explained in detail about space vector pulse width modulation technique of induction motor and simulation model is developed in addition to this it is tested successfully in MATLAB / SIMULINK software.

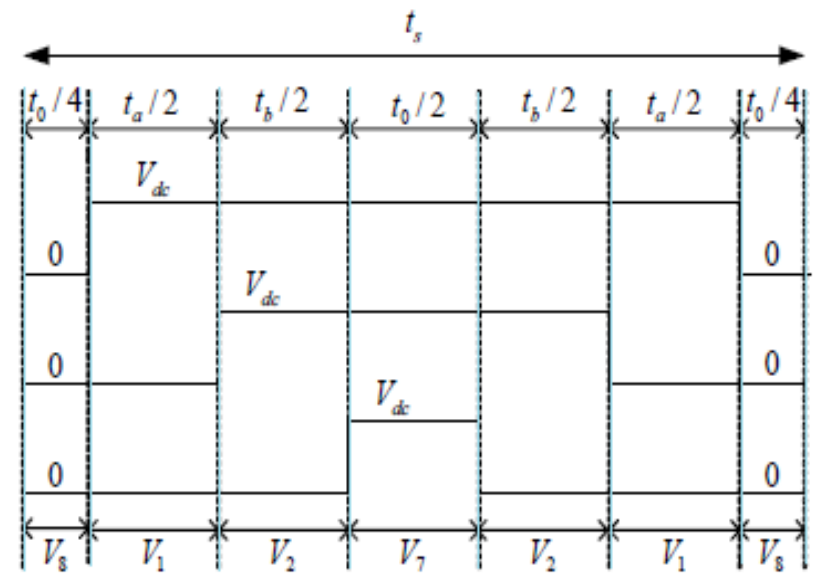

Figure 3: Leg voltage and space vector disposition for one switching period in sector 1

\section{Mathematical Model of Space Vector Pulse Width Modulation}

Step 1: For finding the values of $U_{a}, U_{b}, U_{c}, U_{\text {alpha }}$ and $U_{\text {beta }}$ the equations $1,2,3,4$ and 5 are used.

$$
\begin{array}{r}
U_{a}=u(1) * \sin \{u(2) * 2 * p i * u(3)\} \rightarrow \text { Equation. } 1 \\
U_{b}=u(1) * \sin \left\{u(2) * 2 * p i * u(3)-2 * \frac{p i}{3}\right\} \rightarrow \text { Equation. } 2 \\
U_{b}=u(1) * \sin \left\{u(2) * 2 * p i * u(3)+2 * \frac{p i}{3}\right\} \rightarrow \text { Equation. } 3 \\
U_{\text {alpha }}=\frac{2}{3} *\left(U_{a}-0.5 * U_{b}-0.5 * U_{c}\right) \rightarrow \text { Equation. } 4 \\
U_{\text {beta }}=\frac{2}{3} *\left(\frac{\sqrt{3}}{2} U_{b}-\frac{\sqrt{3}}{2} U_{c}\right) \rightarrow \text { Equation. } 5
\end{array}
$$

Step 2: To Find the suitable sector judgment

$$
\begin{gathered}
U_{\text {beta }}>0, A=1 \rightarrow \text { Equation. } 6 \\
3 U_{\text {alpha }}-U_{\text {beta }}>0, B=1 \rightarrow \text { Equation. } 7 \\
3 U_{\text {alpha }}+U_{\text {beta }}>0, C=1 \rightarrow \text { Equation. } 8
\end{gathered}
$$

Once A, B, C values are determined then find the $\mathrm{N}$ value, by substituting the values of $\mathrm{A}, \mathrm{B}, \mathrm{C}$ in equation 9 .

$$
N=A+2 B+4 C \rightarrow \text { Equation.9 }
$$

\begin{tabular}{|c|c|c|c|c|c|c|}
\hline Sector & I & II & III & IV & V & VI \\
\hline $\mathrm{N}$ & 3 & 1 & 5 & 4 & 6 & 2 \\
\hline
\end{tabular}

Step 3: Calculate the operating time of the fundamental vectors The values of $\mathrm{X}, \mathrm{Y}, \mathrm{Z}$ are calculated by the following equations,

$$
\begin{gathered}
X=2 T\left(U_{\text {beta }}\right) /\left(2 * U_{d c}\right) \rightarrow \text { Equation.10 } \\
Y=T\left(3 U_{\text {alpha }}+U_{\text {beta }}\right) /\left(2 * U_{d c}\right) \rightarrow \text { Equation. } 11 \\
Z=T\left(-3 U_{\text {alpha }}+U_{\text {beta }}\right) /\left(2 * U_{d c}\right) \rightarrow \text { Equation. } 12 \\
T_{1}+T_{2} \leq T \rightarrow \text { Equation.13 } \\
\text { If } T_{1}+T_{2} \geq T \rightarrow \text { Equation.14 then, } \\
T_{1}=T_{1}\left\{T /\left(T_{1}+T_{2}\right)\right\} \rightarrow \text { Equation.15 } \\
T_{2}=T_{2}\left\{T /\left(T_{1}+T_{2}\right)\right\} \rightarrow \text { Equation.16 }
\end{gathered}
$$

\begin{tabular}{|c|c|c|c|c|c|c|}
\hline $\mathrm{N}$ & 1 & 2 & 3 & 4 & 5 & 6 \\
\hline $\mathrm{T} 1$ & $\mathrm{Z}$ & $\mathrm{Y}$ & $-\mathrm{Z}$ & $-\mathrm{X}$ & $\mathrm{X}$ & $-\mathrm{Y}$ \\
\hline $\mathrm{T} 2$ & $\mathrm{Y}$ & $-\mathrm{X}$ & $\mathrm{X}$ & $\mathrm{Z}$ & $-\mathrm{Y}$ & $-\mathrm{Z}$ \\
\hline
\end{tabular}

Step 4: Calculate the switching operating time 


\section{International Journal of Science and Research (IJSR) \\ ISSN (Online): 2319-7064}

Index Copernicus Value (2013): 6.14 | Impact Factor (2014): 5.611

$T_{a}=\left\{T-T_{1}-T_{2}\right\} / 4 \rightarrow$ Equation 17

$T_{b}=T_{a}+\left\{T_{1} / 2\right\} \rightarrow$ Equation 18

$T_{c}=T_{b}+\left\{T_{2} / 2\right\} \rightarrow$ Equation. 19

\begin{tabular}{|c|c|c|c|c|c|c|}
\hline $\mathbf{N}$ & 1 & 2 & 3 & 4 & 5 & 6 \\
\hline $\mathrm{Tcm} 1$ & $\mathrm{~Tb}$ & $\mathrm{Ta}$ & $\mathrm{Ta}$ & $\mathrm{Tc}$ & $\mathrm{Tc}$ & $\mathrm{Tb}$ \\
\hline $\mathrm{Tcm} 2$ & $\mathrm{Ta}$ & $\mathrm{Tc}$ & $\mathrm{Tb}$ & $\mathrm{Tb}$ & $\mathrm{Ta}$ & $\mathrm{Tc}$ \\
\hline $\mathrm{Tcm} 3$ & $\mathrm{Tc}$ & $\mathrm{Tb}$ & $\mathrm{Tc}$ & $\mathrm{Ta}$ & $\mathrm{Tb}$ & $\mathrm{Ta}$ \\
\hline
\end{tabular}

\section{V/F Control Method}

The closed loop v/f control of induction motor is nothing but applying a variable voltage and variable frequency to the motor. In addition to this the shaft position encoder or speed sensor is used to monitor the actual speed of the induction motor. Once the actual speed is found then the actual speed is compared with the reference speed. Now the difference between the actual speed and the reference is known as error. This error is processed through a controller and then the frequency of the inverter is fixed. By adding actual speed and slip speed the synchronous speed of the induction motor is obtained and this determines the frequency of inverter. The block diagram of voltage / frequency is shown in figure.4. [9] Has developed a MATLAB / SIMULINK model for voltage / frequency control of three phase induction motor drive with different pulse width modulation techniques and also tested.

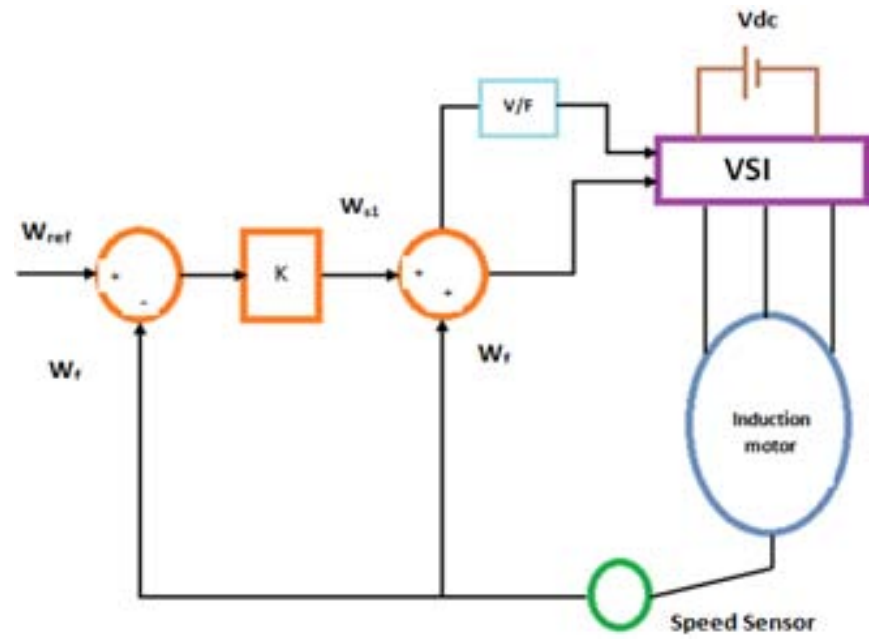

Figure 4: Block diagram of V/F control method

\section{Simulation Model of SVPWM and V/F Control}

The simulation results are given for the induction motor for the following specification:

Number of poles $[\mathrm{P}]=4$, Frequency $[\mathrm{F}]=50 \mathrm{~Hz}$, Number of phases $=3$, Stator resistance $[R s]=6 \mathrm{ohms}$, Rotor resistance $[\mathrm{Rr}]=10 \mathrm{ohms}$, Stator inductance $[\mathrm{Ls}]=450 \mathrm{mH}$, Mutual inductance $[\mathrm{Lm}]=390 \mathrm{mH}$, Moment of inertia $[\mathrm{J}]=0.00388$ $\mathrm{Kg}-\mathrm{m} / \mathrm{sec}$.

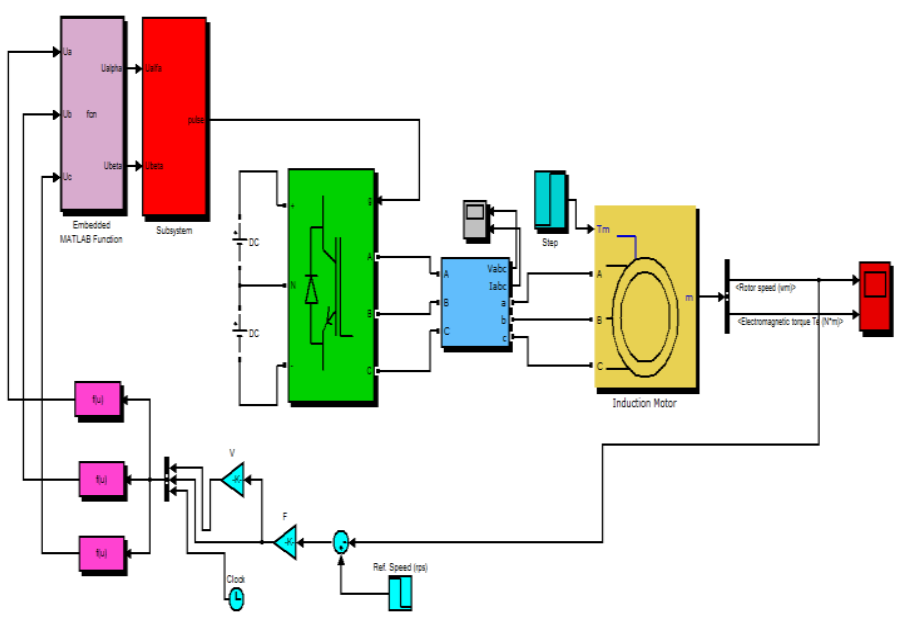

Figure 5: MATLAB simulink model of SVPWM based induction motor

The figure.5 shows the complete MATLAB / SIMULINK model of the space vector pulse width modulation based induction motor with $\mathrm{v} / \mathrm{f}$ control. The step by step subsystem model of the SVPWM method is shown figure.6, figure.7, figure.8, figure.9, figure.10 and figure.11. These subsystem models are designed on the basis of the mathematical equation of SVPWM methods as it is discussed in chapter 3.

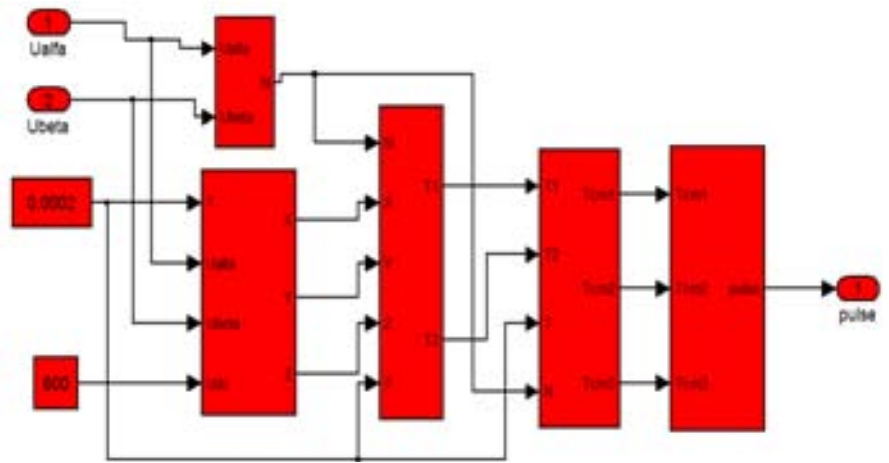

Figure 6: MATLAB simulink subsystem model for the generation of gate pulse

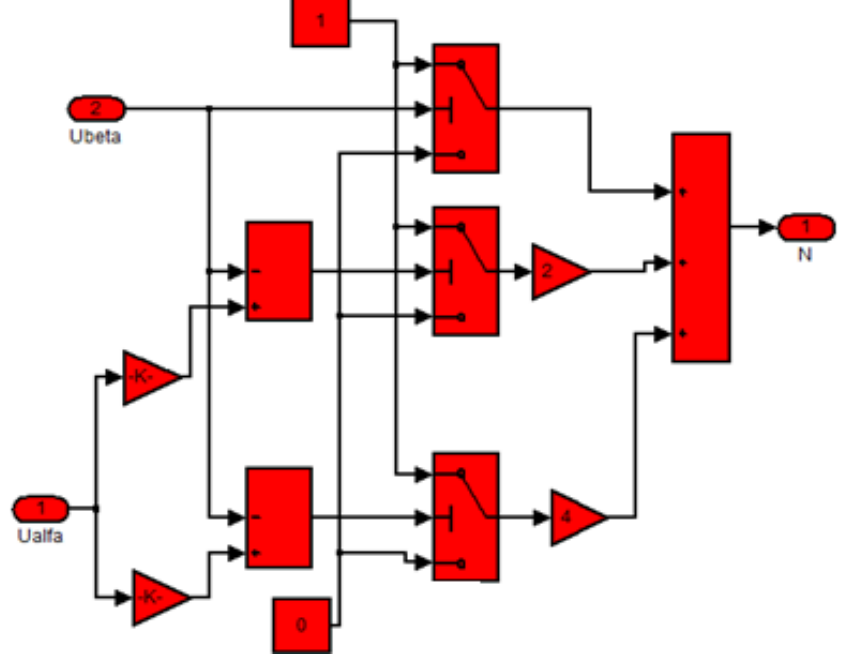

Figure 7: MATLAB simulink subsystem model for sector judgment 


\section{International Journal of Science and Research (IJSR)}

ISSN (Online): 2319-7064

Index Copernicus Value (2013): 6.14 | Impact Factor (2014): 5.611



Figure 8: MATLAB simulink subsystem model for calculating $\mathrm{X}, \mathrm{Y}, \mathrm{Z}$

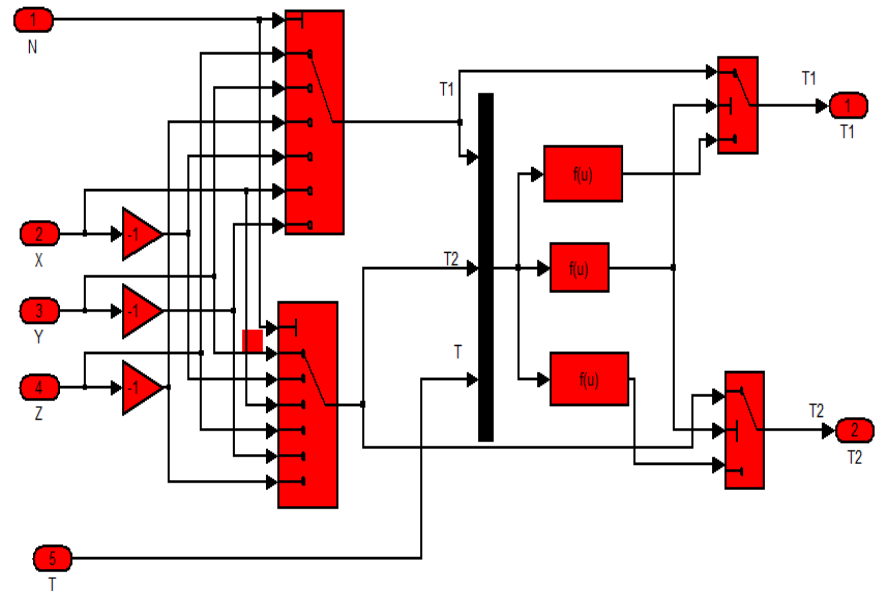

Figure 9: MATLAB simulink subsystem model for calculating operating time of the fundamental vectors

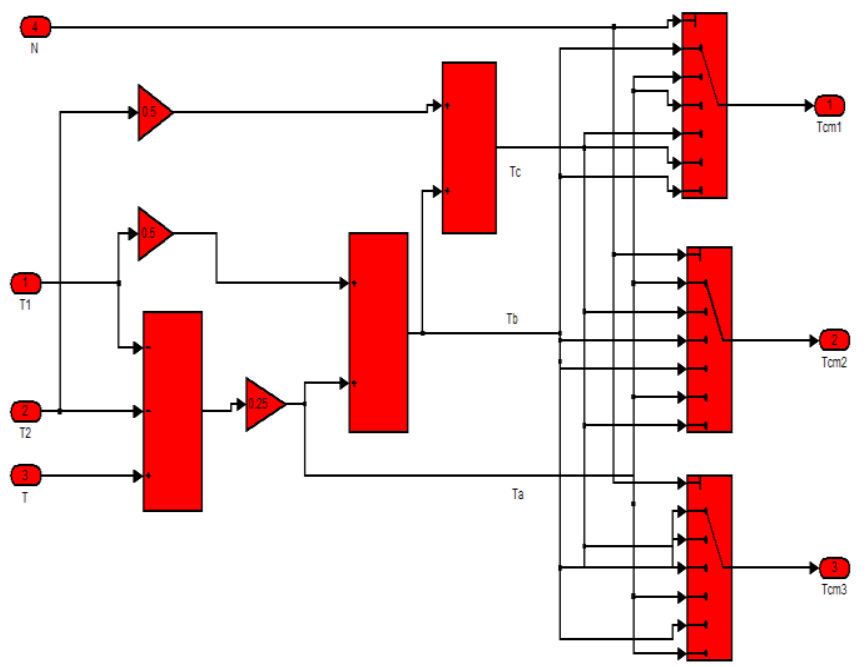

Figure 10: MATLAB simulink subsystem model for calculating switching operating time

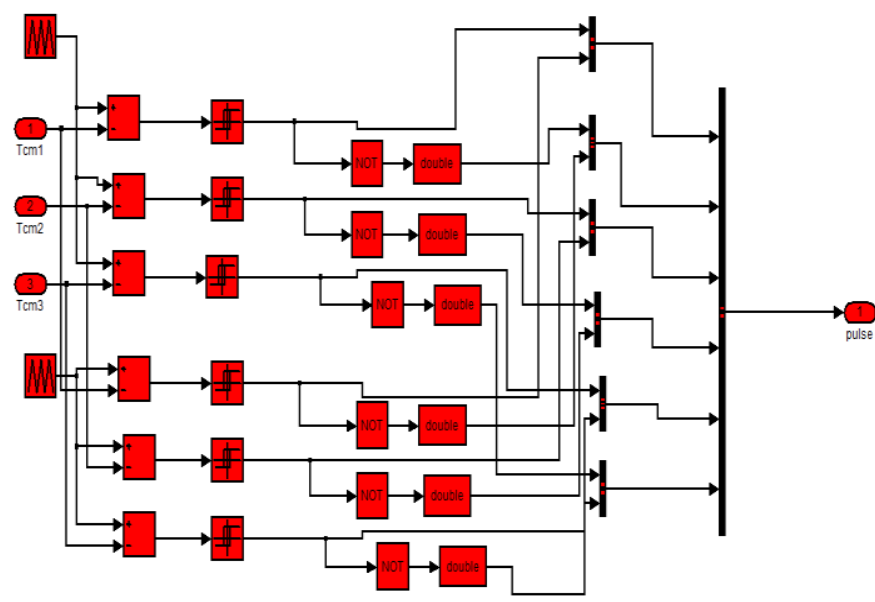

Figure 11: MATLAB simulink subsystem model for generating SVPWM

\section{Simulation Results}

\subsection{Stator Current}

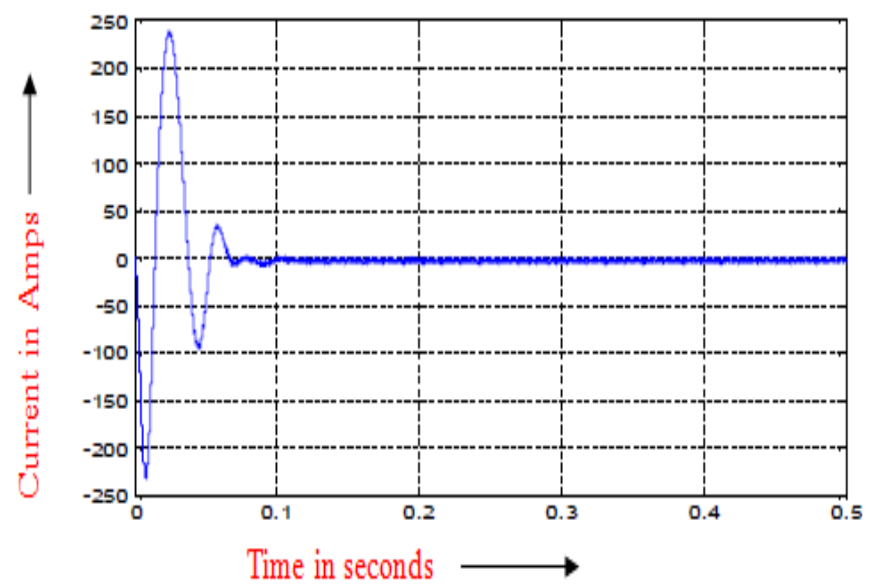

Figure 12: Stator current

\subsection{Rotor Current}

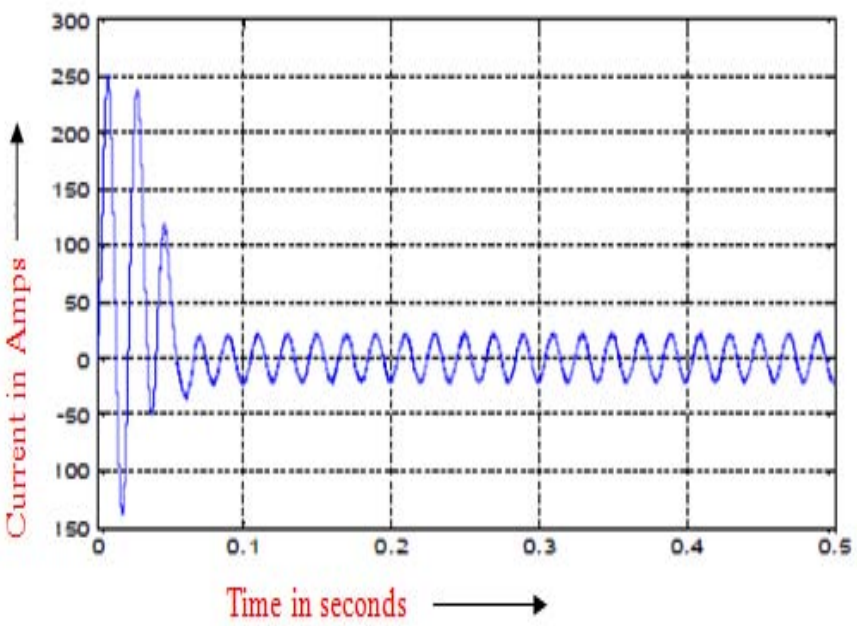

Figure 13: Rotor current

Volume 5 Issue 2, February 2016 


\section{International Journal of Science and Research (IJSR)}

ISSN (Online): 2319-7064

Index Copernicus Value (2013): 6.14 | Impact Factor (2014): 5.611

\subsection{Speed}

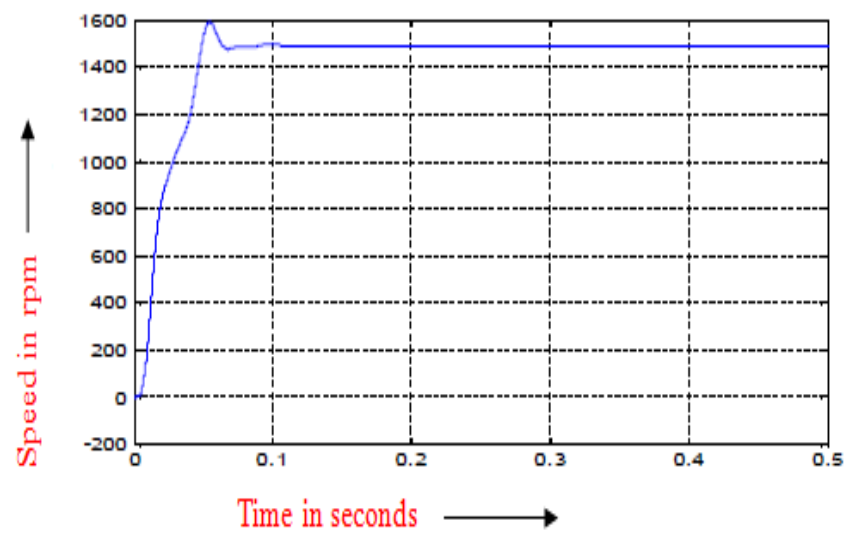

Figure 14: Speed

\subsection{Torque}

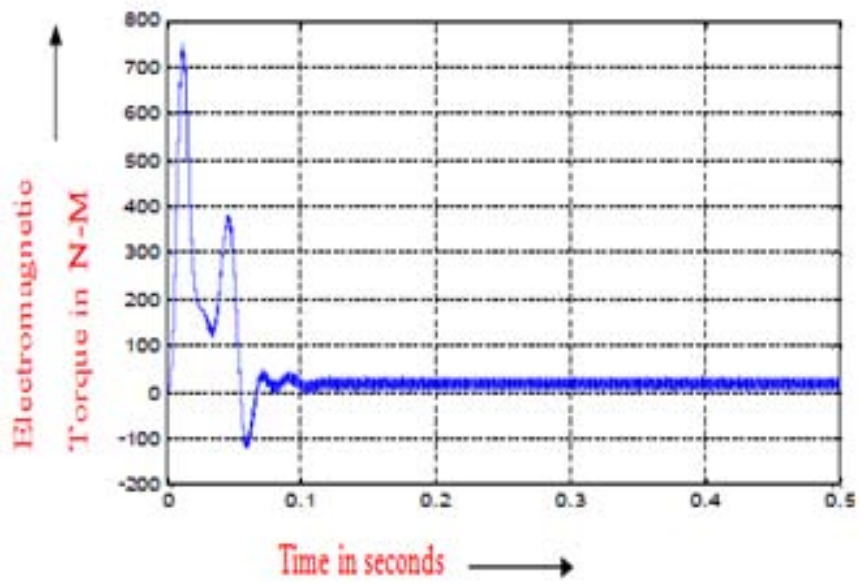

Figure 15: Torque

\section{Conclusion}

In this research paper space vector pulse width modulation based induction motor with $\mathrm{v} / \mathrm{f}$ control model is designed through MATLAB software and also tested successfully by evaluating the parameters like stator current, stator current, torque and speed. . It is due to its characteristics like good power factor, extremely rugged and high efficiency. This scheme leads to be able to adjust the speed of the motor by control the frequency and amplitude of the stator voltage, the ratio of stator voltage to frequency should be kept constant. In addition to that the design and implementation of an induction in simulink is uncomplicated and trouble free. These types of induction motors can be used in lathes, drilling machines, lifts, cranes, conveyors, industrial drives, agricultural and industrial pumps.

\section{References}

[1] P. C. Krause, O. Wasynczuk, S. D. Sudhoff "Analysis of Electric Machinery and Drive Systems", IEEE Press, A
John Wiley \& Sons, Inc. Publication Second Edition, 2002.

[2] H. C. Stanley, "An Analysis of the Induction Motor", AIEE Transactions, Vol. 57 (Supplement), pp. 751-755, 1938.

[3] Burak Ozpineci, L.M.Tolbertr, Simulink Implementation of Induction Machine Model-A modular approach, IEEE rans.2003.

[4] S. A. Shirsavar, M. D. McCulloch and C. G. Guy, "Speed Sensor less Vector Control of Induction Motor with Parameter Estimation, "IEEE Conf. On Industrial Applications, vol.1, pp. 262-269, 1996.

[5] R. Linga Swamy and P. Satish Kumar, "Speed Control of Space Vector Modulated Inverter Driven Induction Motor" Proceedings of the International Multi Conference of Engineers and Computer Scientists 2008 Vol. III MECS 2008 March, pp 19-21.

[6] M Kubeitari, "Space Vector PWM Simulation for Three Phase DC/AC inverter", World Academy of Science, Engineering and Technology 70 2012, pp 136-144.

[7] K. Vinoth Kumar, Prawin Angel Michael, Joseph P. John and Dr. S. Suresh Kumar,"Simulation and comparison of spwm and svpwm control for three phase inverter" ISSN 1819-6608, ARPN Journal of Engineering and Applied Sciences, Vol. 5, No. 7, July 2010.

[8] Shilpa V. Kailaswar and Prof. R.A.Keswani, "Speed Control of Three Phase Induction Motor by V/f Method for Batching Motion System" International Journal of Engineering Research and Applications (IJERA) ISSN: 2248-9622 www.ijera.com Vol. 3, Issue 2, March -April 2013, pp.1732-1736.

[9] El-Nobi A. Ibrahim1 Mohamed Elbesealy, "V/F control of Three Phase Induction Motor Drive with Different PWM Techniques", Innovative Systems Design and Engineering ,ISSN:2222-1727 (Paper) ISSN 2222-2871 (Online), March 2013Vol.4, No.14.pp131-144.

\section{Author Profile}

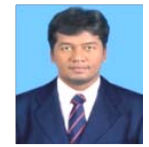

Mr. J. Vikramarajan received his Master degree in Power Electronics and Drives and Bachelor degree in Electrical and Electronics Engineering from VIT University, India. He has published several international research books and journals. His research interests are electrical machines, power electronic applications, power quality, power electronic converters and power electronic controllers for renewable energy systems. 